\title{
Profile of Extrovert and Introvert Personality and The Implications in Problem Based History Learning
}

\author{
Megiridha Loppies, Aip Badrujaman, Sarkadi
}

Universitas Negeri Jakarta
Ipsmegi91@gmail.com

\author{
Article History \\ accepted 1/09/2020
}

approved 4/10/2020

published 1/12/2020

\begin{abstract}
This research is motivated by differences in personality types that caused by differences in thinking abilities which also have an impact on student learning outcomes. The purposes of this study was to identify and analyze the personality types of students and their implications for learning history at SMAS Pusaka 1 Jakarta. The personality types that used in this study are extrovert and introvert personality types according to Carl Gustaf Jung (Arip et al., 2017). The subjects in this study were students of class XI IPS at SMAS Pusaka 1 Jakarta for the 2020/2021 school year. The method used in this research is descriptive qualitative using a questionnaire to collect data on student personality types and then analyzed descriptively. The results showed that extrovert students were more able to build work communication in groups so that they could find more information related to the problems given. However, the information managed by extrovert students is still superficial and less logical. Meanwhile, introverted students are able to use information in answering the problems given by in-depth analysis. The implication of this research is teachers must be able to better understand the personality types of students, both extrovert and introvert to generate more effective learning.
\end{abstract}

Keywords:Personality types, history learning, problem based learning.

\begin{abstract}
Abstrak
Penelitian ini di latarbelakangi oleh adanya perbedaan tipe kepribadian yang menyebabkan perbedaan kemampuan berpikir yang berdampak pula pada hasil belajar siswa. Tujuan penelitian ini adalah untuk mengidentifikasi dan menganalisis tipe kepribadian siswa dan implikasinya dalam pembelajaran sejarah di SMAS Pusaka 1 Jakarta. Tipe kepribadian yang digunakan dalam penelitian ini adalah tipe kepribadian ekstrovert dan introvert menurut Carl Gustaf Jung (Arip et al., 2017). Subjek dalam penelitian ini adalah siswa kelas XI IPS SMAS Pusaka 1 Jakarta tahun ajaran 2020/2021. Metode yang di gunakan dalam penelitian ini adalah deskriptif kualitatif yang menggunakan kuisioner untuk mengumpulkan data tipe kepribadian siswa dan selanjutnya di analisis secara deskriptif. Hasil penelitian menunjukan bahwa siswa ekstrovert lebih mampu membangun komunikasi kerja dalam kelompok sehingga menemukan lebih banyak informasiinformasi yang berkaitan dengan permasalahan yang di berikan. Namun, informasi-informasi yang di kelola oleh siswa ekstrovert masih dangkal dan kurang logis. Sedangkan siswa introvert mampu menggunakan informasi-informasi dalam menjawab permasalahan yang diberikan dengan analisis yang mendalam. Implikasi dari penelitian ini adalah guru harus lebih bisa memahami tipe kepribadian siswa, baik ekstrovert dan introvert untuk membangkitkan pembelajaran yang lebih efektif.
\end{abstract}

Kata kunci: Tipe kepribadian, pembelajaran sejarah, pembelajaran berbasis masalah.

Social, Humanities, and Education Studies (SHEs): Conference Series https://jurnal.uns.ac.id/shes

p-ISSN 2620-9284

e-ISSN 2620-9292 


\section{PENDAHULUAN}

Sejarah merupakan mata pelajaran penting karena mengandung nilai-nilai kehidupan pada masa lampau yang dapat di jadikan sebagai pedoman dalam bertutur dan bertindak untuk masa depan yang lebih baik (Supardi, 2014). Sejarah juga bertujuan untuk membangun kebijaksanaan dalam diri peserta didik yang belajar dari peristiwa masa lampau. Oleh karena itu, mata pelajaran sejarah mesti mampu menjadi pengikat konstruksi nasionalisme. Sejarah mempunyai kedudukan sebagai pengingat umat manusia untuk selalu sadar dan tidak terjebak ke dalam pengalaman buruk masa lalu yang tercermin dalam cerita sejarah. Dalam konteks nasionalisme, sejarah memberi peringatan kepada kita tetang pentingnya memahami identitas kebangsaan yang kita miliki dengan cara menengok kembali pada masa lalu pada waktu identitas tersebut terbentuk.

Mengingat peranan mata pelajaran sejarah yang begitu penting, maka cara mengajar guru di harapkan bisa menggunakan strategi dan model-model pembelajaran inovatif agar dapat mendorong pengembangan keterampilan yang sangat berguna bagi siswa melalui hasil belajar pada aspek kognitif, psikomotor, dan afektif (Khoiriyah \& Husamah, 2018). Demikian pula melalui pembelajaran sejarah yang baik dan benar, terbentuklah sebuah pemahaman dan cara berpikir rasional dalam diri siswa sehingga tujuan pembelajaran dapat tercapai dengan maksimal. Pemahaman dan cara berpikir tersebut di dasarkan pada kecenderungan berpikir yang merefleksikan nilai-nilai positif dari peristiwa sejarah dalam kehidupan sehari-hari sehingga menjadi pribadi yang lebih bijak dalam melihat dan merespon berbagai masalah kehidupan yang dihadapinya. Dengan demikian sejarah yang diajarkan dengan baik dapat menolong manusia menjadi kritis dan memiliki sikap dan cara berpikir yang berperi-kemanusiaan. Sebaliknya kalau diajarkan secara salah dapat mengubah manusia menjadi penganut-penganut suatu aliran yang berlebih-lebihan dan menjadi orang yang fanatik.

Salah satu upaya yang dapat di lakukan untuk meningkatkan hasil belajar siswa adalah dengan menggunakan model pembelajaran berbasis masalah (problem based learning). Pembelajaran berbasis masalah adalah suatu metode pembelajaran yang di mengacu pada paradigma konstruktivisme (Erawanto \& Santoso, 2016) Belajar menurut pandangan aliran konstruktivisme merupakan proses pembelajaran yang menerangkan bagimana pengetahuan di susun dalam diri manusia. Dalam proses belajar mengajar, guru tidak serta merta memindahkan pengetahuan kepada siswa dalam bentuk yang serba sempurna, tetapi siswa dididik untuk membangun pengetahuannya sendiri berdasarkan pengalaman masing-masing. Model pembelajaran ini diharapkan dapat di kembangkan untuk meningkatkan kompetensi dan hasil belajar siswa dalam pembelajaran sejarah. Pembelajaran berbasis masalah menggunakan masalah aktual dan otentik lingkungan sosial sebagai konteks sosial (Serafín et al., 2015) sehingga siswa di latih untuk berpikir kritis dan kreatif guna mendapatkan pengetahuan untuk belajar memecahkan masalah dan membuat keputusan (McParland et al., 2004; Khoiriyah \& Husamah, 2018 ). Pada akhirnya, pembelajaran berbasis masalah memberikan kesempatan bagi siswa untuk "learn how to learn", yang artinya belajar bagaimana belajar (Hallinger \& Bridges, 2017).

Menurut Ihm et al., (2017) faktor non kognitif yang di soroti dalam memprediksi pencapaian dan kompetensi siswa dalam implementasi pembelajaran berbasis masalah adalah tipe kepribadian dan dinamika kelompok. Hal ini diperkuat oleh Hallinger \& Bridges, (2017) yang menyatakan bahwa efektifitas pembelajaran berbasis masalah sangat di pengaruhi oleh karakteristik siswa, di antaranya perbedaan peran dalam organisasi, gender, usia, tingkat pengalaman, tipe kepribadian dan orientasi kultural. Dari argumen inilah dapat di ketahui bahwa salah satu karakteristik siswa yang mempengaruhi efektivitas pembelajaran berbasis masalah adalah tipe kepribadian. 
Kepribadian merupakan sifat esensial seseorang yang tercermin dalam sikap dan tindakan yang membedakan dirinya dari orang lain (Sari et al., 2020). Feist dan Feist (dalam Fatmawati \& Khabibah, 2019) mendefenisikan kepribadian sebagai pola sifat dan karakteristik tertentu yang relatif permanen, baik konsistensi maupun individualitas pada perilaku seseorang. Dengan demikian, tipe kepribadian mengacu pada klasifikasi tipe individu secara psikologis, dimana terdapat preferensi seseorang dalam melakukan atau menentukan segala sesuatu dalam kehidupannya (Soleimani et al., 2018).

Carl Gustav Jung menyatakan bahwa setiap orang memiliki tipe kepribadian yang berbeda-beda. Dengan demikian, la membagi kepribadian dalam dua kelompok besar yakni, tipe kepribadian ekstovert dan introvert (Ekawati, 2016; Arip et al., 2017). Jung berpendapat bahwa pada setiap diri seseorang terdapat keseimbangan antara dorongan-dorongan kepribadian yang berlawanan. Kepribadian seseorang meliputi ekstrovert dan introvert, rasional dan irasional, laki-laki dan perempuan, kesadaran dan ketidaksadaran serta didorong oleh kejadian-kejadian di masa lalu yang ditarik oleh harapan-harapan di masa depan (Lestari \& Basri, 2019).

Pada penelitian ini, peneliti ingin melihat profil dari tipe kepribadian ekstrovert dan introvert dalam pembelajaran sejarah yang menggunakan model pembelajaran bebasis masalah. Hal ini penting di lakukan mengingat pembelajaran berbasis masalah, urgensinya membutuhkan peran aktif dan kolaboratif siswa dalam pembelajarannya membentuk kelompok, merumuskan masalah dan berdiskusi mengenai masalah yang diberikan. Sementara tidak semua siswa memiliki tipe kepribadian yang sama, yang dapat menunjang proses berjalannya sebuah pembelajaran dengan baik. Dengan demikian, menurut penulis, penelitian mengenai profil tipe kepribadian siswa dan implikasinya dalam pembelajaran sejarah berbasis masalah penting dilakukan agar guru memiliki gambaran tentang tipe kepribadian siswa, sehingga guru memiliki data empiris mengenai tipe kepribadian siswa yang bisa dijadikan pertimbangan atau rujukan dalam melaksanakan pembelajarannya.

\section{Pembelajaran Sejarah}

Pembelajaran merupakan upaya sistematis dan sistemik untuk menginisiasi, memfasilitasi, dan meningkatkan proses belajar, maka berkaitan erat dengan jenis hakikat dan belajar serta hasil belajar (Juniarti, 2014). Menurut Gagne, Briggs dan Wager pembelajaran diartikan sebagai serangkaian kegiatan yang dirancang untuk memungkinkan terjadinya proses belajar pada siswa (Hardiman, 2017). Pembelajaran dapat terjadi manakala adanya interaksi antara guru dan siswa dengan media dan metode pembelajaran.

Menurut Kuntowijoyo, Sejarah dapat dipahamisebagai rekonstruksi kehidupan manusia pada masa lalu tentang suatu peristiwa dalam dimensi waktu dan ruang yang terbingkai dalam ruang dan waktu (Rahayu, 2019). Selanjutnya, Sartono Kartodidjo, berpendapat bahwa ada dua pengertian sejarah yaitu sejarah dalam arti obyektif, dan sejarah dalam arti subjektif. Sejarah dalam arti obyektif menunjuk kepada kejadian atau peristiwa itu sendiri ialah proses sejarah dalam aktualisasinya (Simanjuntak, 2005). Maksudnya bahwa kejadian itu hanya terjadi sekali dan tidak dapat di ulang kembali. Keseluruhan proses itu berlangsung terlepas dari subjek manapun. Obyektif artinya tidak mengandung unsur-unsur subyek pengamat atau pencerita. Sejarah dalam arti subjektif adalah sebuah konstruksi yang berarti bangunan yang di susun penulis sebagai suatu uraian cerita aktualisasinya (Simanjuntak, 2005).

I Gde Widja menjelaskan pembelajaran sejarah sebagaiaktivitas belajarmengajar, didalamnya memuat pelajaran mengenai peristiwa masa lampau yang berhubungan erat dengan masa kini, sebab dengan kacamata masa kini kita mampu mempelajari masa lampau (Fitri, 2020). Bahwa membelajarkan sejarah tidak semata hanya terkait fakta-takta dalam ilmu sejarah namun juga tujuan dari pendidikan pada umumnya, yaitu untuk mencapai kompetensi yang terdiri atas kognitif, afektif, dan 
psikomotorik. Pembelajaran sejarah diharapkan dapat membangun kesadaran, pengetahuan, wawasan, dan nilai berkenaan dengan lingkungan tempat diri dan bangsanya hidup.

\section{Pembelajaran Berbasis Masalah (Problem Based Learning)}

Pembelajaran berbasis masalah (Problem Based Learning) merupakan suatu pendekatan model pembelajaran yang berpusat pada siswa (student centered) (Peranginangin et al., 2019). Model pembelajaran berbasis masalah difokuskan pada masalah otentik di mana siswa dapat membangun pengetahuan mereka sendiri (Sugiarti \& Basuki, 2014), mengembangkan keterampilan bertanya dan berpikir tingkat tinggi untuk mencarikan solusi atas masalah yang di berikan (Hmelo-Silver, 2004) serta bertanggung jawab atas pembelajarannya sendiri (Hmelo-Silver \& Barrows, 2006).

Menurut Uden and Beaumont pembelajaran berbasis masalah adalah sebuah model pembelajaran konstruktivistis yang tidak hanya menolong siswa untuk memecahkan masalah tetapi juga guru dan pengajarannya untuk berpikir memecahkan masalah sebelum konten pembelajaran di perkenalkan (Ismail et al., 2018). Hal ini di tegaskan pula oleh Arends yang menyatakan bahwa pada esensinya pembelajaran berbasis masalah adalah model pembelajaran yang berlandaskan konstruktivisme dan mengakomodasikan keterlibatan siswa dalam belajar serta terlibat dalam pemecahan masalah yang kontekstual (Wulansari et al., 2019).

Dalam pembelajaran berbasis masalah, guru bertindak sebagai fasilitator dan pemberi petunjuk keada siswa. Peran siswa lebih di arahkan untuk aktif mencari informasi lewat berbagai sumber belajar seperti pada buku, jurnal dan internet dan setelah itu mendiskusikan berbagai hasil temuannya dengan siswa lain di dalam kelompok terkait masalah yang akan di cari solusinya, setelah itu di presentasikan di depan kelas. Proses pembelajaran yang demikian membuat siswa terlatih untuk belajar mandiri, berpikir kritis, dan mampu mencari solusi atas setiap permasalahan yang akan di hadapinya kelak di dunia nyata.

Menurut Barrows, (1996) karakteristik pembelajaran berbasis masalah adalah sebagai berikut:

1. Pembelajaran yang berpusat pada siswa (Student centered).

2. Pembelajaran terjadi dalam kelompk-kelompok kecil siswa.

3. Guru sebagai fasilitator atau pemberi petunjuk.

4. Dalam belajar, masalah didapatkan dari pengorganisasian tujuan dan stimulus.

5. Masalah adalah kendaraan untuk mengembangkan keterampilan pemecahan masalah.

6. Informasi baru diperoleh melalui pembelajaran arahan sendiri.

Tujuan utama pengembangan model pembelajaran berbasis masalah adalah agar siswa memiliki kemampuan berpikir kritis dan kemampuan pemecahan masalah dan sekaligus mengembangkan kemampuan mereka secara aktif membangun pengetahuan sendiri. Hmelo-Silver, (2004) mengemukakan bahwa pembelajaran berbasis masalah di desain untuk beberapa tujuan penting untuk menolong siswa:

1. membangun basis pengetahuan yang luas dan fleksibel

2. mengembangkan keterampilan pemecahan masalah yang efektif;

3. mengembangkan keterampilan belajar mandiri dan terarah seumur hidup;

4. menjadi kolaborator yang efektif;

5. menjadi termotivasi secara intrinsik untuk belajar.

John Dewey kemudian merumuskan tujuh langkah yang harus dilakukan dalam pelaksanaan strategi pembelajaran berdasarkan masalah. Ketujuh langkah tersebut adalah sebagai berikut:

1. Merumuskan permasalahan, merupakan langkah pertama yang dilakukan peserta didik berupa penentuan masalah yang akan dipecahkan.

2. Menganalisis masalah, adalah langkah kedua peserta didik berupa peninjauan masalah untuk dikritisi berdasarkan anekai sudut pandang. 
3. Merumuskan hipotesis, adalah langkah ketiga peserta didik dalam memecahkan masalah yang sudah ditentukan sebelumnya berdasarkan pengetahuan yang mereka miliki.

4. Mengumpulkan data, yaitu langkah keempat yang dilakukan peserta didik guna mendapatkan informasi dalam upaya memecahkan masalah.

5. Pengujian hipotesis, adalah langkah kelima yang dilakukan peserta didik menyusun kesimpulan berdasarkan hipotesis yang telah diajukan sebelumnya.

6. Merumuskan rekomendasi terhadap masalah yang dipecahkan, yaitu langkah keenam yang dilakukan peserta didik yang menggambarkan rumusan hasil penyelidikannya.

7. Menguji hipotesis yang sudah disusun dan merumuskan kesimpulan (Indrahadi \& Junaidi, 2017).

\section{Kepribadian}

Menurut Adolf Heuken seperti yang di kutip oleh Bahrudin, (2019), kapribadian adalah pola yang menyeluruh dari semua kemampuan, perbuatan serta kebiasaan seseorang, baik jasmani, mental, rohani, emosional maupun sosial. Kepribadian mencakup seluruh kemampuan manusia dan segenap pengalaman sepanjang kehidupannya (Yusra et al., 2015).

Bahwasannya tipe kepribadian mempunyai peran penting dalam menyukseskan pendidikan dan hasil jangka panjang seseorang (Husain \& Adam, 2018). Jika di hubungkan dengan pembelajaran berbasis masalah, maka tipe kepribadian adalah salah satu faktor dari karakteristik pribadi siswa yang turut mempengaruhi efektivitas model pembelajaran berbasis masalah (Hallinger \& Bridges, 2017; Ihm et al., 2017).

Carl Gustaf Jung seorang ahli Psikologis asal Swiss (Kurniawan \& Stanislaus, 2016; Nurcahya \& Mulyana, 2017) adalah orang yang mengembangkan teori bahwa dalam diri masing-masing individu terdapat unsur psikologis yang di sebut kepribadian. la menggolongkan kepribadian atas dua golongan besar yaitu: ekstrovert dan introvert. Mitchellette (dalam Khalil, 2016) melakukan analisis mendalam mengenai ekstrovert dan introvert dan menyimpulkan bahwa ekstrovert memiliki keterampilan komunikasi dan interaksi yang lebih baik daripada introvert. Orang ekstrovert terbukti menjadi pembicara publik yang lebih baik daripada introvert. Namun, tidak berarti bahwa introvert kurang percaya diri atau tidak bisa menghadapi orang. Orang ekstrovert memiliki kemampuan meyakinkan yang baik, tetapi introvert memiliki wawasan dan dapat diandalkan. Sementara Castro mendefinisikan orang introvert sebagai orang yang memiliki energi batin terhadap pikiran dan gagasan. Otak mereka tidak bekerja dalam keadaan hiperaktif dan mereka sering mencari inspirasi pada orang lain. Sebaliknya mereka mencari perlindungan dalam kesepian dan belajar dari ide dan konsep. Selain itu, introvert juga membuat seseorang menjadi tidak ekspresif, sehingga relatif sulit untuk memahami orang yang introvert daripada ekstrovert (Khalil, 2016).

Tipe kepribadian ektrovert adalah tipe keribadian yang lebih berorientasi ke dunia luar. Eysenck dan Eysenck (dalam Arini \& Rosyidi, 2016) mengemukakan bahwa hal yang khas dari ekstrovert adalah mudah bergaul, suka pesta, mempunyai banyak teman, membutuhkan teman untuk bicara,dan tidak suka membaca atau belajar sendirian, sangat membutuhkan kegembiraan, mengambil tantangan, sering menentang bahaya, berperilaku tanpa berpikir terlebih dahulu, dan biasanya suka menurutkan kata hatinya, gemar akan gurau-gurauan, selalu siap menjawab, dan biasanya suka akan perubahan, riang, tidak banyak pertimbangan, optimis, suka tertawa dan gembira, lebih suka untuk tetap bergerak dalam melakukan aktivitas, dan cenderung menjadi agresif. Seorang ekstrovert akan lebih berprinsip praktis, cepat bertindak, cepat mengambil keputusan karena orientasi hidup masa kini. Tipe ini lebih suka turut serta aktif di tengah orangorang sehingga mudah menyesuaikan diri dan biasanya di senangi lingkungannya. 
Orang ekstrovert memiliki karakteristik utama yaitu kemampuan bersosialisasi dan sifat impulsive, senang bercanda, penuh gairah, cepat dalam berfikir, optimis, serta sifat-sifat lain yang mengindikasikan orang-orang yang menghargai hubungan mereka dengan orang lain (Yusra et al., 2015).

Sedangkan tipe kepribadian introvert adalah kebalikan dari introvert. la lebih mengutamakan pikiran, perasaan cita-cita sendiri menjadi sumber dan minatnya, merenung, dan merencanakan sehingga tampak menyendiri, tingkah laku yang lamban dan ragu-ragu serta tidak suka dengan pola kehidupan yang melibatkan banyak orang (Jamil, 2012). Feist \& Feist (dalam Husain \& Adam, 2018) menyatakan bahwa umumnya orang introvert senang introspektif dan sibuk dengan kehidupan mereka sendiri. Individu seperti ini lebih mementingkan dunia internal meliputi pikiran, perasaan, fantasi, dan mimpi. Mereka lebih berfokus ke dalam dirinya sendiri. Sesorang introvert memiliki kecenderungan felling yang akan disalurkan melalui introspeksi dan tersibukkan dengan pengalaman dalam diri, yang mungkin akan dianggap orang lain sebagai bentuk ketidakacuhan atau sikap dingin dan ironis sehingga hal ini dinilai orang lain sebagai individu yang kurang memiliki peduli terhadap orang lain (Arip et al., 2017).

Pujianto et al., (2015) menggambarkan karakteristik orang yang bertipe keribadian introvert antara lain cenderung untuk mengembangkan gejala-gejala ketakutan, mudah tersinggung, apatis, syaraf otonom mereka stabil. Pada akhirnya, Eysenck dan Eysenck (dalam Arini \& Rosyidi, 2016) sampai pada kesimpulan bahwa: hal yang khas dari introvert adalah pendiam, pemalu, mawas diri, gemar membaca, suka menyendiri dan menjaga jarak, kecuali dengan teman yang sudah akrab, cenderung merencanakan lebih dahulu, melihat dulu sebelum melangkah dan curiga, tidak suka kegembiraan, menjalani kehidupan sehari-hari dengan keseriusan dan menyukai gaya hidup yang teratur dengan baik, menjaga perasaannya secara tertutup, jarang berperilaku agresif, tidak menghilangkan kemarahannya, dapat dipercaya, dalam beberapa hal pesimis dan mempunyai nilai standar etika yang tinggi.

\section{METODE}

Metode yang digunakan dalam penelitian ini adalah deskriptif kualitatif untuk mendeskripsikan profil kepribadian siswa dan implikasinya dalam pembelajaran sejarah berbasis masalah. Penelitian dilakukan pada bulan Agustus sampai September 2020 di SMAS Pusaka 1 Jakarta. Subjek yang dipilih adalah siswa kelas XI yang memenuhi syarat, yakni 34 siswa kelas XI IPS3 masing-masing dengan tipe ekstrovert 24 orang dan tipe introvert 10 orang yang di analisis berdasarkan hasil kuisioner tipe kepribadian yang di sebar kepada ketiga puluh empat siswa di SMAS Pusaka 1 Jakarta dalam pembelajaran Sejarah yang menggunakan model pembelajaran berbasis masalah (problem based learning).

\section{HASIL DAN PEMBAHASAN}

Pada bagian ini, disajikan gambaran data hasil pengolahan setelah kuisioner tipe kepribadian disebar dan dikumpulkan. Data tersebut kemudian diolah menggunakan pendekatan statistika, yang hasilnya dapat dilihat sebagai berikut.

Tabel 1: Data profil kepribadian ekstrovert dan Introvert Siswa

\begin{tabular}{lllll}
\hline Kepribadian & No Soal & Jumlah Soal & Jumlah Siswa & Persentase (\%) \\
\hline Ekstrovert & $1-15$ & 15 & 24 & 70,58 \\
Introvert & $16-30$ & 15 & 10 & 29,4 \\
Jumlah & 30 & 30 & 34 & 100 \\
\hline
\end{tabular}


Data kuisioner tipe kepribadian yang dibagikan kepada 34 orang siswa yang dipilih sebagai subjek penelitian, hasilnya menunjukan 24 orang siswa berkepribadian ekstrovert dan 10 siswa lainnya bertipe kepribadian introvert.

Dari ke-34 siswa tersebut yang telah di ketahui tipe kepribadiannya, maka di buatlah kelompok siswa berdasarkan tipe kepribadian untuk pembelajaran sejarah yang menggunakan model pembelajaran berbasis masalah (problem based learning), yang terdiri dari dua kelompok ekstrovert dan satu kelompok introvert. Dua kelompok ekstrovert tersebut masing-masing terdiri dari 12 siswa dalam satu kelompok dan satu kelompok introvert yang terdiri dari 10 orang siswa.

Berdasarkan hasil belajar pada mata pelajaran sejarah yang menggunakan model pembelajran berbasis masalah, maka diperoleh deskripsi mengenai tipe kepribadian ekstrovert dan introvert sebagai berikut:

\section{Subjek Ekstrovert}

a. Merumuskan masalah

Pada tahap merumuskan masalah, subjek ekstrovert dapat merumuskan masalah dengan baik. Subjek ekstrovert dapat merumuskan masalah yakni: mengapa revolusi-revolusi besar dunia (seperti revolusi Amerika, revolusi Prancis, revolusi Rusia, revolusi Tiongkok dan revolusi Indonesia) bisa terjadi dan bagaimana pengaruhnya bagi umat manusia hingga masa kini.

b. Menganalisis masalah

Dalam tahap menganalisis masalah, subjek ekstrovert dapat menganalisis masalah terjadinya revolusi-revolusi besar dunia (seperti revolusi Amerika, revolusi Prancis, revolusi Rusia, revolusi Tiongkok dan revolusi Indonesia) dan pengaruhnya bagi umat manusia hingga masa kini dengan baik. Subjek ekstrovert dapat melakukan analisis masalah sambil bertukar pikiran antara satu dengan yang lain. Mereka saling berdiskusi untuk mendapatkan jawaban yang tepat. Namun, subjek ekstrovert dalam melakukan analisis masalah cenderung masih dangkal dan kurang logis.

c. Merumuskan hipotesis

Dalam merumuskan hipotesis atau jawaban yang benar, subjek ekstrovert dapat dengan mudah berkolaborasi dengan teman-temannya dalam satu kelompok untuk mendiskusikan kemungkinan jawaban yang benar. Subjek ekstrovert sangat cepat dalam merumuskan hipotesis dan mengkomunikasikannya di dalam kelompok. Mereka saling membagi tugas untuk merumuskan hipotesis dan kemudian akan di rangkum dalam satu kertas jawaban. Sehingga tugas mereka sangat cepat selesai.

d. Mengumpulkan data

Dalam mengumpulkan data terkait masalah yang akan di pecahkan, subjek ekstrovert sangat kreatif. Mereka mengumpulkan data dari bermacam sumber seperti buku teks, ada juga yang mengumpulkan data dari internet, ada juga yang dari vidio atau film-film sejarah yang berkaitan dengan materi yang di ajarkan. Subjek ekstrovert sangat aktif dan cepat dalam mengelola data dan informasi yang mereka temukan.

e. Pengujian hipotesis

Dalam tahap pengujian hipotesis, subjek ekstrovert dapat melakukan pengujiannya dengan baik. Mereka dapat melakukan pengujian hipotesis atas masalah berdasarkan informasi-informasi yang mereka temukan pada tahap mengumpulkan data. Namun mereka belum mampu menghubungkan 
dengan baik informasi-informasi yang mereka dapatkan dengan masalah yang ada.

f. Merumuskan rekomendasi terhadap masalah yang dipecahkan

Dalam merumuskan rekomendasi terhadap masalah yang di pecahkan, subjek ekstrovert dapat memberikan rekomendasi yang tepat. Subjek ekstrovert dapat memberikan rekomendasi dengan alasan yang cukup logis.

g. Menguji hipotesis yang sudah disusun dan merumuskan kesimpulan

Dalam menguji hipotesis, subjek ekstrovert bisa melakukannya dengan baik, namun pengujian yang mereka lakukan masih dangkal. Mereka juga dapat merumuskan kesimpulan akhir dengan benar.

\section{Subjek Introvert}

a. Merumuskan masalah

Pada tahap merumuskan masalah, subjek introvert dapat merumuskan masalah dengan baik. Sama seperti subjek ekstrovert, masalah yang dirumuskan subjek introvert adalah mengapa dan bagaimana terjadinya revolusi-revolusi besar dunia (seperti revolusi Amerika, revolusi Prancis, revolusi Rusia, revolusi Tiongkok dan revolusi Indonesia) bisa terjadi dan bagaimana pengaruhnya bagi umat manusia hingga masa kini.

b. Menganalisis masalah

Dalam menganalisis masalah, subjek introvert sangat fokus kepada masalah yang di berikan untuk dianalisis sehingga mereka pada akhirnya dapat menganalisis masalah dengan sangat radikal. Subjek introvert yang bekerja dalam kelompok seperti mengabaikan aspek diskusi bersama dalam kelompok. Masing-masing dari mereka cenderung bekerja sendiri-sendiri. Setelah masing-masing mereka selesai mengerjakannya barulah tugas mereka disatukan. Dengan demikian, subjek introvert membutuhkan lebih banyak waktu untuk menyelesaikan tugasnya namun sangat berhati-hati dan teliti dalam mengaitkan informasi-informasi yang dianalisisnya.

c. Merumuskan hipotesis

Subjek introvert dapat merumuskan hipotesis dengan baik berdasarkan analisis yang telah dilakukannya dengan sangat tajam dan cermat. Dengan demikian hipotesis yang dihasilkan dari subjek introvert merupakan hasil analisis yang lebih tajam dan radikal dibandingkan dengan subjek ekstrovert.

d. Mengumpulkan data

Dalam mengumpulkan data, subjek introvert bisa dengan mudah mendapatkan data dan informasi dari berbagai media seperti buku teks, internet maupun vidioa dan film. Namun komunikasi pada subjek introvert dalam kelompok cenderung pasif sehingga mereka membutuhkan waktu yang lebih banyak untuk menyelesaikan tugas.

e. Pengujian hipotesis

Dalam hal pengujian hipotesis, subjek introvert dapat melakukannya berdasarkan hasil analisis yang telah di lakukan sebelumnya. Subjek introvert dapat menguji hipotesis dengan alasan logis dan mendalam di sertai buktibukti yang relevan.

f. Merumuskan rekomendasi terhadap masalah yang dipecahkan

Pada tahap ini, subjek introvert telah memiliki alasan yang kuat untuk merumuskan rekomendasi terhadap masalah yang diberikan. Subjek 
introvert dapat merekomendasikan hal-hal positif yang dapat dipelajari berkaitan dengan masalah.

g. Menguji hipotesis yang sudah disusun dan merumuskan kesimpulan

Subjek introvert dapat menguji hipotesis dan merumuskan kesimpulan akhir atas masalah yang telah di bahas. la dengan tajam dan alasan yang sangat kuat dapat menguji hipotesis yang telah dirumuskan.

Perbedaan tipe kepribadian siswa, baik ekstrovert maupun introvert telah ada dan terbentuk secara alami dalam dirinya masing-masing. Selain dipengaruhi oleh faktor bawaan sejak lahir, kebiasaan atau bahkan faktor lingkungan membawa implikasi dalam proses pendidikan seseorang di sekolah. Dalam hal ini, dalam pembelajaran di sekolah harus menyesuaikan dengan tipe kepribadian siswa. Hal ini penting karena tidak semua siswa memiliki tipe kepribadian yang sama, sehingga cara belajar, gaya belajar atau bahkan sikap siswa dan responnya terhadap pembelajaran itu berbeda-beda.

Selanjutnya, pemahaman tentang kepribadian siswa memiliki arti penting dalam interaksi belajar mengajar. Seorang guru mesti memahami informasi mengenai kepribadian siswanya karena sebagai akan sangat berguna dalam memilih dan menentukan pola-pola pengajaran yang lebih tepat dan lebih baik, yang dapat menjamin kemudahan belajar bagi setiap siswa. Dengan pemahaman inilah, guru dapat merekonstruksi dan mengorganisasi materi pelajaran, memilih dan menentukan metode, yang tepat agar interaksi dari berbagai komponen pembelajaran itu dapat saling mengisi. Selain itu, pemahaman atas tipe kepribadian siswa berfungsi sebagai informasi bagi guru untuk memberikan motivasi dan bimbingan bagi setiap siswa.

Uraian diatas memperlihatkan bahwa pemahaman tentang tipe kepribadian siswa merupakan hal penting yang harus dimiliki oleh setiap guru agar dapat menciptakan suatu iklim sekolah yang baik. Apabila hal ini terjadi maka siswa akan merasa nyaman untuk belajar dan berada di sekolah. Dengan begitu, tujuan pembelajaran dapat tercapai dengan maksimal.

\section{SIMPULAN}

Berdasarkan uraian di atas, maka dapat disimpulkan bahwa: Setiap siswa memiliki tipe kepribadian yang berbeda-beda. Ada siswa yang memiliki tipe kepribadian ekstrovert dan ada siswa yang berkepribadian introvert.

Tipe ektrovert adalah seseorang yang cenderung lebih berorientasi ke luar. la mudah bergaul, suka mengambil tantangan, lancar dalam berbicara, bebas dari rasa takut, tidak mudah bingung, berpegang pada data-data objektif, senang bergaul, dan suka bekerjasama dengan orang lain, suka pesta, membutuhkan teman untuk bicara, sangat membutuhkan kegembiraan, suka mengambil tantangan, biasanya suka menurutkan kata hatinya, selalu siap menjawab, dan biasanya suka akan perubahan, tidak banyak pertimbangan, optimis, dan lebih suka untuk tetap bergerak dalam melakukan aktivitas, dan cenderung menjadi agresif. Seorang ekstrovert akan lebih berprinsip praktis, cepat bertindak, cepat mengambil keputusan karena orientasi hidup masa kini.

Sementara tipe kepribadian introvert adalah kebalikan dari Ekstrovert. Seorang introvert cenderung lebih berorientasi ke dalam. Secara esensial, hal yang khas dari introvert adalah pendiam, pemalu, mawas diri, gemar membaca, suka menyendiri dan menjaga jarak, kecuali dengan teman yang sudah akrab, cenderung merencanakan lebih dahulu, melihat dulu sebelum melangkah dan curiga, tidak suka kegembiraan, menjalani kehidupan sehari-hari dengan keseriusan dan menyukai gaya hidup yang teratur dengan baik, menjaga perasaannya secara tertutup, jarang berperilaku agresif, 
dapat dipercaya, dalam beberapa hal pesimis dan mempunyai nilai standar etika yang tinggi.

Implikasi dari adanya perbedaan tipe kepribadian tersebut adalah pentingnya pemahaman terhadap setiap tipe kepribadian siswa agar menjadi pedoman bagi guru maupun penyelenggara pendidikan agar dapat menyesuaikan pembelajaran dengan tipe kepribadian siswa. Perlu diketahui bahwa pemahaman terhadap tipe kepribadian siswa akan mempermudah guru dalam melakukan interaksi dan umpan balik dalam kegiatan pembelajaran, sehingga siswa merasa nyaman untuk belajar.

\section{DAFTAR PUSTAKA}

Arini, Z., \& Rosyidi, A. H. (2016). Pofil Kemampuan Penalaran Siswa SMP Dalam Menyelesaikan Masalah Matematika Ditinjau Dari Tipe Kepribadian Extrovert dan Introvert. Jurnal IImiah Pendidikan Matematika, 2(5), 127-136.

Arip, M. A. S. M., Mohammad, N. H., Ibrahim, N. H., \& Husin, N. S. (2017). Validity and Reliability Development of Extrovert and Introvert Personality Inventory among University Students. International Journal of Academic Research in Business and Social Sciences, 7(9), 450-463. https://doi.org/10.6007/IJARBSS/v7-i9/3340

Bahrudin, E. R. (2019). Profil Pemahaman Konsep Siswa Kelas Vii Materi Bangun Datar Ditinjau Dari Tipe Kepribadian Ekstrovert Dan Introvert. EDU-MAT: Jurnal Pendidikan Matematika, 7(2), 168-176. https://doi.org/10.20527/edumat.v7i2.6408 Barrows, H. S.

(1996). Problem-Based Learning in Medicine and Beyond: A Brief Overview. New Directions for Teaching and Learning, 68, 3-12.

Ekawati, H. (2016). Perbedaan Penerapan Model Pembelajaran Pembelajaran Kooperatif Tipe Think-Pair-Share dan Pembelajaran Konvensioanl Pada Kelas VII SMP Negeri 10 Samarinda. Jurnal Pendas Mahakam, 1(1), 54-64.

Erawanto, U., \& Santoso, E. (2016). Pengembangan Modul Pembelajaran Berbasis Masalah Untuk Membantu Meningkatkan Berfikir Kreatif Mahasiswa. JINoP (Jurnal Inovasi Pembelajaran), 2(2), 427. https://doi.org/10.22219/jinop.v2i2.2629

Fatmawati, I., \& Khabibah, S. (2019). Profil Siswa SMP Dalam Memecahkan Masalah Matematika Ditinjau dari Tipe Kepribadian. Jurnal IImiah Pendidikan Matematika, $8(2), 328-337$.

Fitri, M. (2020). Pembelajaran Sejarah HOTS Zaman Now Melalui Model Problem Based Learning Sebagai Upaya Meningkatkan kemampuan Berpikir Historis Peserta Didik. 1-12.

Hallinger, P., \& Bridges, E. M. (2017). A Systematic Review of Research on the Use of Problem-Based Learning in the Preparation and Development of School Leaders. Educational Administration Quarterly, 53(2), 255-288. https://doi.org/10.1177/0013161X16659347

Hardiman. (2017). Pengembangan Pembelajaran Berbantuan Komputer Mata Kuliah Materi dan Pembelajaran IPS SD Untuk Mahasiswa. Jurnal Pendidikan Surya Edukasi (JPSE, 3, 42-54.

Hmelo-Silver, C. E. (2004). Problem-Based Learning: What and How Do Students Learn? Educational Psychology Review, 16(3), 235-266. https://doi.org/1040726X/04/0900-0235/0

Hmelo-Silver, C. E., \& Barrows, H. S. (2006). Goals and Strategies of a Problem-based Learning Facilitator. Interdisciplinary Journal of Problem-Based Learning, 1(1), 522. https://doi.org/10.7771/1541-5015.1004

Husain, B., \& Adam, S. S. (2018). Differences in The Achievement Of English Language Essence Between Introvert and Extrovert. International Journal Of Education, 
Information Trechnology, and Others, 1(2), 1-13. https://doi.org/10.5281/zenodo.1492945

Ihm, J., An, S., \& Seo, D. (2017). Do Dental Students' Personality Types and Group Dynamics Affect Their Performance in Problem-Based Learning? Dental Education, 81(6), 744-751. https://doi.org/10.21815/JDE.017.015

Indrahadi, D., \& Junaidi. (2017). Upaya Meningkatkan Kemampuan Peserta Didik Berpikir Kritis Melalui penerapan Srategi pembelajaran Berbasis Masalah Pada Pembelajaran Sosiologi Kelas XI IPS 2 SMA Negeri 1 Pariaman. Jurnal Socius: Journal of Sociology Research and Education, 4(1), 22-30. https://doi.org/10.24036/scs.v4i1.14

Ismail, N. S., Harun, J., Aman, M. Z. M. Z., \& Salleh, S. (2018). The Effect of Mobile Problem-Based Learning Application DicScience PBL on Students' Critical Thinking. Thinking Skills and Creativity. https://doi.org/10.1016/j.tsc.2018.04.002

Jamil, M. (2012). Kepuasan Interaksi Sosial Lansia Dengan Tipe Kepribadian. Jurnal Keperawatan, 3(2), 171-182. https://doi.org/https://doi.org/10.22219/jk.v3i2.2594

Juniarti, T. (2014). Model Pembelajaran Kontekstual Berbasis Masalah Terhadap Hasil Belajar Siswa Tunarungu. Jurnal Pendidikan Khusus Unesa.

Khalil, R. (2016). Influence of extroversion and introversion on decision making ability. International Journal of Research in Medical Sciences, 4(3), 1534-1538. https://doi.org/10.18203/2320-6012.ijrms20161224

Khoiriyah, A. J., \& Husamah, H. (2018). Problem-based learning: Creative thinking skills, problem-solving skills, and learning outcome of seventh grade students. Jurnal Pendidikan Biologi Indonesia, 4(2), 151-160. https://doi.org/10.22219/jpbi.v4i2.5804

Kurniawan, M. F., \& Stanislaus, S. (2016). Perilaku Pro-Sosial Ditinjau dari Tipe Kepribadian Introvert dan Ekstrovert (Studi pada Mahasiswa Psikologi UNNES). Jurnal IImiah Psikologi, 8(3), 195-199. https://doi.org/http://journal.unnes.ac.id/nju/index.php/INTUISI

Lestari, A., \& Basri, W. (2019). Meningkatkan Minat Belajar Sejarah Siswa Melalui Model Quantum Teaching. JUrnal Penelitian Aktual Dan Kajian Reformasi Pendidikan, 17(1), 1-12.

McParland, M., Noble, L. M., \& Livingston, G. (2004). The effectiveness of problembased learning compared to traditional teaching in undergraduate psychiatry. Medical Education 2004; $\quad$ 859-867. https://doi.org/10.1046/j.13652929.2004.01818.x

Peranginangin, S. A., Saragih, S., \& Siagian, P. (2019). Development of Learning Materials through PBL with Karo Culture Context to Improve Students' Problem Solving Ability and Self-Efficacy. International Electronic Journal of Mathematics Education, 14(2), 265-274. https://doi.org/10.29333/iejme/5713

Pujianto, A., Nuryatin, A., \& Subyantoro. (2015). Keefektifan Pembelajaran Keterampilan Menulis Cerpen Dengan Model Investigasi Kelompok Dan Model Stad Berdasarkan Tipe Kepribadian Peserta Didik Kelas Vii. Seloka: Jurnal Pendidikan Bahasa Dan Sastra Indonesia, 4(2), 131-139.

Rahayu, W. (2019). Pembelajaran Sejarah untuk generasi Z. JURNAL PENDIDIKAN SEJARAH INDONESIA, 2(1), 1-7.

Sari, H. I., Munawaroh, M., \& Raharjo, H. (2020). Analysis of Student's Creative Thinking Ability in Mathematical Problem Solving in Terms of Extrovert and Introvert Personality Types. Eduma: Mathematics Education Learning and Teaching, 9(1), 34. https://doi.org/10.24235/eduma.v9i1.6153

Serafín, Č., Dostál, J., \& Havelka, M. (2015). Inquiry-Based Instruction in the Context of Constructivism. Procedia - Social and Behavioral Sciences, 186, 592-599. https://doi.org/10.1016/j.sbspro.2015.04.050

Simanjuntak, P. (2005). Gerakan Sosial Sebagai Peristiwa Sejarah. In Historisme Edisi 
Khusus (Vol. 10, Issue 21). http://repository.usu.ac.id/handle/123456789/15308

Soleimani, N., Nagahi, M., Nagahisarchoghaei, M., \& Jaradat, R. (2018). The

Relationship between Personality Types and the Cognitive - Metacognitive Strategies. Journal of Studies in Education, 8(2), 29-44. https://doi.org/10.5296/jse.v8i2.12767

Sugiarti, S., \& Basuki. (2014). Pengaruh model pembelajaran berbasis masalah terhadap kemampuan koneksi matematika siswa dalam pembelajaran matematika. Jurnal Pendidikan Matematika, 3(3), 151-158. https://media.neliti.com/media/publications/226603-pengaruh-modelpembelajaran-berbasis-mas-c45daf56.pdf

Supardi, S. (2014). Pendidikan Multikultural Dalam Pembelajaran Sejarah Lokal. Jurnal Pembangunan Pendidikan: Fondasi Dan Aplikasi, 2(1), 91-99. https://doi.org/10.21831/jppfa.v2i1.2621

Ulger, K. (2018). The effect of problem-based learning on the creative thinking and critical thinking disposition of students in visual arts education. Interdisciplinary Journal of Problem-Based Learning, 12(1). https://doi.org/10.7771/1541-5015.1649

Wulansari, T., Putra, A., Rusliah, N., \& Habibi, M. (2019). Pengaruh Model Pembelajaran Berbasis Masalah Pada Materi Statistika Terhadap Kemampuan Penalaran Statistis Siswa. Jurnal Aksioma: Jurnal Matematika Dan Pendidikan Matematika, 10(1), 35-47.

Yusra, M. S., Tjalla, A., \& Marjo, H. K. (2015). Empati Dasar Mahasiswa Bk Berdasarkan Tipe Kepribadian Introvert Dan Ekstrovert Angkatan 2011 Di Universitas Negeri Jakarta. Insight: Jurnal Bimbingan Konseling, 4(2), 69-74. https://doi.org/10.21009/insight.042.12 